\title{
Alpha particle detector based on micro pixel avalanche photodiodes
}

\author{
F.Ahmadov ${ }^{*}, * * * *$, O.Abdinov ${ }_{* *}^{* *}$, G.Ahmadov $^{*}, * * * *$, N.Anfimov ${ }_{*}^{*}$, \\ A.Garibov ${ }^{*}$, E.Guliyev ${ }_{*}^{*}$, Z.Krumshtein ${ }^{*}$, R.Madatov ${ }_{* * * *}$, \\ A.Olshevski ${ }^{*}$, V.Shvetsov $^{*}$, A.Sadigov $^{*}, * * *$, Z.Sadygov $^{*}{ }^{* *}$, \\ A.Titov ${ }^{*}$, V.Zhezher" \\ *Joint Institute for Nuclear Research, 6 Joliot-Curie St., \\ 141980 Dubna, Moskovskaya obl., Russia \\ $*$ Institute of Physics, National Academy of Sciences of Azerbaijan, \\ 33 H.Cavid Ave., 1143 Baku, Azerbaijan \\ **:* All-Russian Research Institute of Automatics, 22 Suschevskaya St., \\ 127055 Moscow, Russia \\ *:*:*: Institute of Radiation Problems, \\ National Academy of Sciences of Azerbaijan, \\ 9 Vaxabzade St., 1143 Baku, Azerbaijan \\ LLR Ecole Polytechnique, Palaiseau, 91128 Cedex, France
}

\section{Received February 12, 2013}

The main goal of this work is a study of possibility to detect alpha particles by micro-pixel avalanche photodiode (MAPD) which has very thin active volume $(4 \mu \mathrm{m})$ and by micro-pixel avalanche photodiode in combination with Lutetium Fine Silicate (LFS) scintillators (500 $\mu \mathrm{m}$ thickness). The obtained results show that alpha detectors based on MAPD are expected to be useful in many applications: public security (Associated Particle Imaging for explosives and drugs detection), radioactive contamination monitoring in various environments and detection of charged particles from nuclear reactions.

Изучены возможности регистрации альфа-частиц с помощью микропиксельного лавинного фотодиода (МЛФД) с очень тонкой активной областью (4 $\mu \mathrm{m})$ и МЛФД в комбинации со сцинтиллятором ортосиликата лютеция толщиной $500 \mu \mathrm{m}$. Полученные результаты показывают, что основанные на МЛФД альфа-детекторы могут быть полезными в следующих областях: общественная безопасность (обнаружение взрывчатых и наркотических веществ), мониторинг радиоактивного загрязнения окружающей среды и обнаружение заряженных частиц от ядерных реакций.

Детектори альфа-частинок на основі мікропіксельних лавінних фотодіодів. Ф.Ахмедов, Г.Абдінов, Г.Ахмедов, Н.Анфімов, А.Гарібов, Е.Гулієв, З.Крулштейн, Р.Мадатов, А.Ольшевський, В.Шиецов, А.Садигов, З.Садигов, А.Тітов, В.Жежер.

Вивчено можливості реєстрації альфа-частинок за допомогою мікропіксельного лавинного фотодіоду (МЛФД) з дуже тонкою активною областю (4 $\mu \mathrm{m})$ і МЛФД в комбінації зі сцинтилятором ортосилікату лютецію товщиною $500 \mu \mathrm{m}$. Отримані результати показують, що засновані на МЛФД альфа-детектори можуть бути корисними у наступних областях: громадська безпека (виявлення вибухових і наркотичних речовин), моніторинг радіоактивного забруднення навколишнього середовища i виявлення заряджених частинок від ядерних реакцій. 


\section{Introduction}

Challenges of the last decade have made detection of explosives and drugs in baggage and large cargoes an important task. Neutron based detection techniques have shown to be very promising in detection and identification of those (Associated particle imaging). Neutrons can penetrate deeply into luggage and cargo and interact with nuclei in the materials producing characteristic gamma spectra [1].

The main idea of this method is creation of neutrons in the generator as a result of deuterium beam interaction with tritium target. The interaction is accompanied by emission of alpha particles flying in opposite to the neutrons direction. Capture of neutrons within a given nucleus produces a specific for the resulting isotope gamma spectrum. Analysis of the gamma spectrum allows one to determine atomic composition of the substance and identify it. Detection of the alpha particle allows one to determine the neutron direction and generate a trigger signal. This helps to detect the necessary signal even in a presence of a large background. Therefore development of fast alpha particle detectors has a growing interest.

It is well known that MAPD has good timing characteristics and radiation hardness. Therefore the most challenging task in this work is the registration of alpha particles by the MAPD which has very thin $(4 \mu \mathrm{m})$ active volume in regular APD mode and by Geiger mode MAPD in combination with the LFS scintillator.

\section{Experimental}

Design and operation principles of the MAPD were described in $[2,3]$. Tested devices MAPD-3N (regular APD mode) and MAPD-3N1P (Geiger mode) had $3 \times 3 \mathrm{~mm}^{2}$ active area, the thickness of active layer was $4-7 \mu \mathrm{m}$ and pixel density -15000 pixels $/ \mathrm{mm}^{2}$. Gains of MAPD-3N and MAPD$3 \mathrm{~N} 1 \mathrm{P}$ diodes were 60 and $5.5 \cdot 10^{4}$, respectively, at operating voltage. Capacitance of the MAPD diodes reached up to $120 \mathrm{pF}$. Maximum photon detection efficiency of the MAPD-3N1P was more than $30 \%$ around 450-525 nm photon wavelengths. Dark currents of MAPD-3N and MAPD-3N1P diodes were $4 \mathrm{nA}$ and $77 \mathrm{nA}$, respectively, at operating voltage.

The LFS crystal of LFS-8 type was used as a scintillator. The size of the LFS- 8 was $3 \times 3 \times 0.5 \mathrm{~mm}^{3}$. The decay time of LFS- 8 was 19 ns. LFS-8 was coupled to the MAPD-

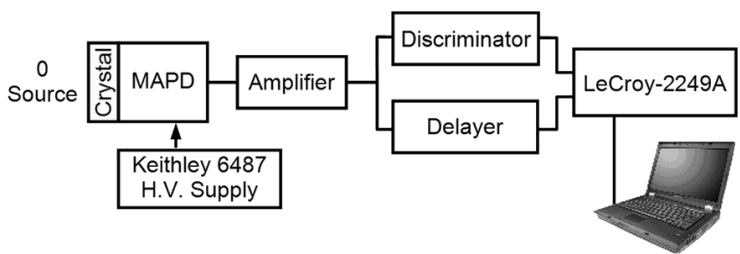

Fig. 1. Block diagram of the experimental setup.

3N1P with silicone optical grease. The tested MAPD samples and LFS scintillator were developed in collaboration with Zecotek Photonics Singapore Pte. Ltd. [4].

${ }^{241} \mathrm{Am}$ radionuclide was used as a source of alpha particles with energy $5.486 \mathrm{MeV}$. Distance between the MAPD diode and the alpha particle source was $1 \mathrm{~cm}$, therefore, alpha particle energy loss in the air was about $1 \mathrm{MeV}$ and remaining energy was about $4.5 \mathrm{MeV}$.

Fig. 1 shows block diagram of the experiment setup. High voltage power supply Keithley 6487 was used for MAPD biasing. The spectrum measurements were performed with linear amplifiers, CAEN N-48 shaping discriminator and LeCroy $2249 \mathrm{~W}$ ADC. Amplified and delayed signal was fed into the ADC. CAEN N-48 shaping discriminator was used to form a gate signal for the ADC. All measurements were carried out at room temperature.

\section{Results and discussion}

The MAPD-3N operating in regime of convenient APD was used for direct detection of alpha particles from ${ }^{241} \mathrm{Am}$ source. When alpha particle penetrates into the diode it generates electron-hole pairs. Alpha particle loses about $700 \mathrm{keV}$ (for $0^{\circ}$ incident angle) in the $4 \mu \mathrm{m}$ thick depletion region.

The alpha spectra were taken at MAPD bias voltages in the range of 50-126.5 V. The spectra obtained at all bias voltages differed substantially from the spectrum obtained with a conventional semiconductor detector. The first major difference was observation of two peaks $(50-115 \mathrm{~V})$ corresponding to the same particle energy (Fig. 2a). Positions of the primary (left) peak depended strongly on the bias voltage (or gain) while dependence on the voltage of the secondary peak was much weaker. With further increasing voltage and gain the secondary peak became wider and proportion between peak areas changed (Fig. 2b). The possible explanation of this is following. In the case of small incident angles, most of electrons (several hundred thousands) pro- 

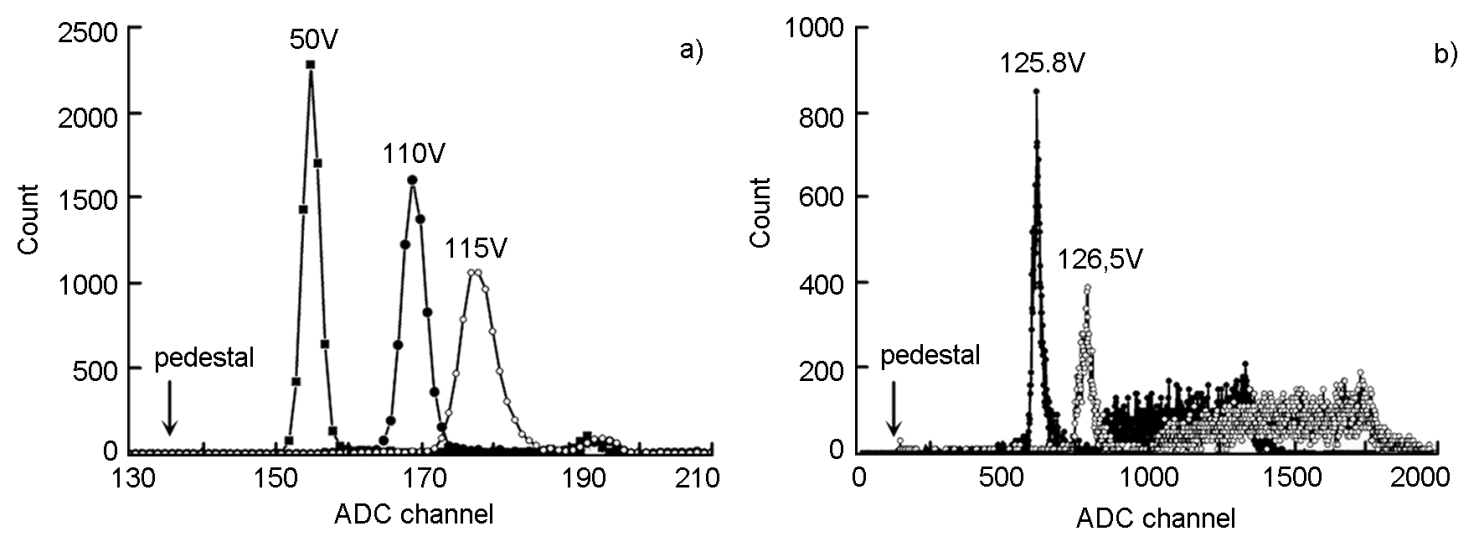

Fig. 2. Set of alpha spectra recorded by MAPD-3N avalanche photodiode: a) bias voltage $50-115 \mathrm{~V}$ and amplifier gain 83 and b) bias voltage 125.8-126.5 V and amplifier gain 23.

duced by alpha particle hit the same pixel or area between two or four adjacent pixels within very short time (several ns). Due to gain saturation in the first case the pixel does not work in normal mode (or does not multiply electrons in normal mode) while in the second case (hitting area between two or four adjacent pixels) charge is spread between the pixels and that does not cause such saturation.

In order to measure alpha spectra by LFS scintillator, the later was placed on top of the MAPD-3N1P surface with a thin layer of optical grease between them under the source of ${ }^{241} \mathrm{Am}$. The alpha spectrum from LFS scintillator was taken at MAPD bias voltage $94 \mathrm{~V}$ (Fig. 3). When alpha particle penetrates into the scintillator, it deposits its entire energy. The deposited energy converts into scintillation light which is isotropically emitted from the alpha particle track. The scintillation light was detected by the MAPD-3N1P. Edges of the scintillator were covered by $5 \mu \mathrm{m}$ thick aluminum foil.

Two peaks are well seen in Fig. 3. It is known that ${ }^{241} \mathrm{Am}$ source emits $59.6 \mathrm{keV}$ gamma rays as well. To confirm that the first peak was due to the gamma ray thick aluminum layer was placed between the ${ }^{241} \mathrm{Am}$ source and the scintillator. Alpha particles absorbed in the aluminum and single gamma ray peak was observed in the spectrum. Energy resolution for $4.5 \mathrm{MeV}$ alpha particles was $8.6 \%$.

The obtained results show that MAPD$3 \mathrm{~N} 1 \mathrm{P}$ in combination with LFS scintillator

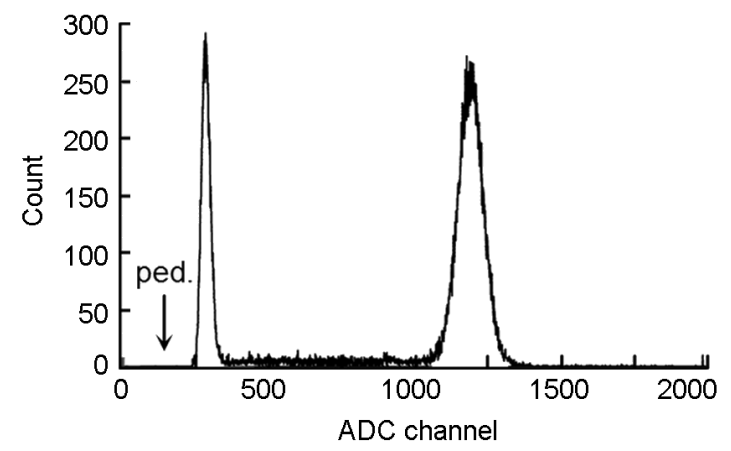

Fig. 3. Amplitude spectrum of ${ }^{241} \mathrm{Am}$ source obtained by MAPD-3N1P coupled with LFS scintillator (signal amplified 30 times).

can be used as fast alpha particle detectors for public security (Associated Particle Imaging for explosives and drugs detection). In addition, these kinds of detectors can be used for monitoring radioactive contamination in various environments and charged particles detection from nuclear reactions. Behavior of the MAPD-3N requires further investigation which is planned in the nearest future.

\section{References}

1. In: Proc. of 19th Int. Seminar on Interaction of Neutrons with Nuclei, (Dubna, 2011), JINR (2011), p.231.

2. Z.Ya.Sadygov, Patent No.2316848 [in Russian].

3. Z.Sadygov, A.F.Zerrouk, T.Bokova et al., Nucl. Instrum. Meth. Phys. Res. A, 610, 390 (2009).

4. www.zecotek.com 